\title{
The indole-3-carbinol cyclic tetrameric derivative CTet inhibits cell proliferation via overexpression of p21/CDKN1A in both estrogen receptor- positive and triple-negative breast cancer cell lines
}

Mauro De Santi ${ }^{1}$, Luca Galluzzi ${ }^{1}$, Simone Lucarini ${ }^{2}$, Maria Filomena Paoletti ${ }^{1}$, Alessandra Fraternale ${ }^{1}$, Andrea Duranti ${ }^{2}$, Cinzia De Marco ${ }^{3}$, Mirco Fanelli ${ }^{1}$, Nadia Zaffaroni ${ }^{3}$, Giorgio Brandi $^{{ }^{*}}$ and Mauro Magnani ${ }^{1}$

\begin{abstract}
Introduction: Indole-3-carbinol (I3C), an autolysis product of glucosinolates present in cruciferous vegetables, and its dimeric derivative $\left(3,3^{\prime}-\mathrm{DIM}\right)$ have been indicated as promising agents in preventing the development and progression of breast cancer. We have recently shown that ISC cyclic tetrameric derivative CTet formulated in $\gamma$ cyclodextrin $(\gamma-C D)$ efficiently inhibited cellular proliferation in breast cancer cell lines. This study aims to analyze the mechanisms involved in the in vitro inhibition of cell proliferation and to evaluate the in vivo antitumor activity of CTet in a xenograft study.
\end{abstract}

Methods: Estrogen receptor-positive MCF-7 and triple-negative MDA-MB-231 breast cancer cell lines were exposed to CTet to evaluate cell cycle perturbation (propidium iodide staining and cytofluorimetric acquisition), induction of autophagic morphological features (co-localization of LC3b autophagosome marker and LAMP2a lysosome marker by immunofluorescence) and changes in protein expression (immunoblot and microarray-based gene expression analyses). To test the in vivo efficacy of CTet, female athymic nude mice inoculated with MCF-7 cells were i.p. treated with $5 \mathrm{mg} / \mathrm{kg} / \mathrm{day}$ of CTet for five days/week for two weeks and the tumor mass was externally monitored.

Results: CTet induced accumulation in G2/M phase without evidence of apoptotic response induction in both cell lines tested. In triple-negative MDA-MB-231 the autophagic lysosomal activity was significantly up-regulated after exposure to $4 \mu \mathrm{M}$ of CTet for 8 hours, while the highest CTet concentration was necessary to observe autophagic features in MCF-7 cells. The inhibition of Akt activity and p53-independent p21/CDKN1A and GADD45A overexpression were identified as the main molecular events responsible for CTet activity in MCF-7 and p53-mutant MDA-MB-231 cells. In vivo, CTet administration was able to significantly inhibit the growth of MCF-7 xenotransplanted into nude mice, without adverse effect on body weight or on haematological parameters.

Conclusions: Our data support CTet formulated with $\gamma$-CD as a promising and injectable anticancer agent for both hormone-responsive and triple-negative breast tumors.

\footnotetext{
* Correspondence: giorgio.brandi@uniurb.it

'Department of Biomolecular Sciences, University of Urbino 'Carlo Bo', Via

Saffi 2, 61029 Urbino, Italy

Full list of author information is available at the end of the article
} 


\section{Introduction}

Breast cancer is one of the most common malignancies in industrialized countries and is characterized by distinct classes of tumors that respond differently to targeted therapies such as selective estrogen receptor modulator (SERM) treatments (for example, tamoxifen) in estrogen receptor (ER)-positive breast cancer or monoclonal antibodies (for example, trastuzumab) in HER2/Neu-positive breast cancer. However, about 10\% to $15 \%$ of breast cancers do not express ER, progesterone receptor (PR), and HER2/Neu receptor [1,2]. This subgroup, the so-called triple-negative category, is associated with poor prognosis because of its resistance to therapy. Its management includes the use of standard treatment such as platinum-based therapy, anthracycline, and taxanes; nevertheless, it is frequently associated with local and systemic relapse [2]. Therefore, a critical problem in the clinical strategies for the management of breast cancer is the development of molecules with effective activity in the treatments of hormoneresponsive as well as triple-negative tumors. Several clinical trials assessing various therapeutic options, including the use of inhibitors of specific molecular targets such as poly-(ADP-ribose)-polymerase (PARPs) or the mammalian target of rapamycin (mTOR), used as monotherapy or combined with traditional chemotherapy, are currently ongoing [1]. Owing to their implication in several cell responses such as regulation of cell growth, survival, and apoptosis, phosphatidylinositol 3-kinase (PI3K) and the downstream Akt/mTOR pathway represent potential targets for treatment of triplenegative breast cancer [2,3].

Cruciferous vegetable consumption has been associated with lower cancer risk in several epidemiological and dietary studies [4-6]. The chemopreventive properties of these vegetables are attributed to the antitumor activity of indole-3-carbinol (I3C) and its metabolic derivatives, which have shown great potential for both prevention and treatment of cancer through numerous mechanisms such as induction of apoptosis and cell cycle arrest, antiestrogenic activity, gene expression modulation, and prevention of carcinogen-DNA adduct formation $[7,8]$. It has also been reported that I3C and its major condensation product 3,3'-DIM inactivate the Akt signaling pathway in breast cancer cells [9-11]. Nevertheless, the development of I3C as a therapeutic agent is limited by several factors such as its easy conversion into many polymeric products in vivo [12]. These compounds have some common targets but have also been demonstrated to have distinct biological effects on breast cancer cells $[13,14]$ and the relatively high concentrations necessary to inhibit the expression of CDK6 and to induce cell cycle arrest in breast cancer (from 50 to $200 \mu \mathrm{M}$ ) [15,16].
As alternatives to $\mathrm{I} 3 \mathrm{C}$ as a chemotherapeutic agent for the treatment of breast cancer, several I3C derivatives characterized by higher antiproliferative properties have recently been proposed [7,17-19]. I3C cyclic tetrameric derivative CTet $(5,6,11,12,17,18,23,24$-octahydrocyclododeca[1,2-b:4,5- $\left.b^{\prime}: 7,8-b^{\prime \prime}: 10,11-b^{\prime \prime}\right]$ tetraindole) (Figure 1) is an anticancer molecule that has been shown to exert interesting antiproliferative activity in both MCF-7 and MDA-MB-231 breast cancer cell lines [20]. Lucarini and colleagues [21] have optimized a straightforward, reproducible, and scalable CTet synthesis. Moreover, to improve bioavailability, they have optimized a formulation that is based on gamma-cyclodextrin $(\gamma-C D)$ aqueous solution and that is about 10 -fold more active with respect to the first preparation [20].

In this study, we analyze the biological responses in terms of cell cycle perturbations and autophagy induction in both ER-positive (MCF-7) and triple-negative (MDA-MB-231) breast cancer cell lines exposed to CTet obtained by a new synthetic procedure. We also characterize the molecular mechanisms leading to the inhibition of cell proliferation by using microarray-based gene expression analysis. We identified the overexpression of p21/CDKN1A (cyclin-dependent kinase inhibitor 1A) as the strongest molecular event induced by CTet treatment; the inhibition of Akt activity, revealed in CTettreated cells, could be responsible for p21/CDKN1A overexpression in MCF-7 and p53-mutant MDA-MB231 cells. Finally, the toxicity and antitumoral efficacy of the $\gamma$-CD-formulated CTet, obtained in a preliminary xenograft study, are discussed.

\section{Materials and methods Chemistry}

All reagents, with the exception of $\gamma$-CD (CAVAMAX ${ }^{\circledR}$ W8; Wacker, Munich, Germany), were purchased from Sigma-Aldrich (St. Louis, MO, USA) or Carlo Erba (Rodano, Italy) and were the highest quality reagents that were commercially available. Solvents were Carlo Erba analytic grade. Melting point, high-performance liquid chromatography/mass spectrometry (HPLC/MS), ${ }^{1} \mathrm{H}-\mathrm{NMR}$, and ${ }^{13} \mathrm{C}-\mathrm{NMR}$ were determined as in [21]. Purification of the crude material was carried out as in [21]. Thin layer chromatography analyses were performed as in [21].

\section{Synthesis of CTet}

To a solution of 3-[(1H-indol-2-yl)methyl $]-1 H$-indole (2,3'-DIM) [22] (0.246 g, $1 \mathrm{mmol})$ and $37 \%$ aqueous formaldehyde $(0.122 \mathrm{~mL}, 1.46 \mathrm{mmol})$ in methanol $(10 \mathrm{~mL})$, $96 \%$ sulphuric acid $(0.063 \mathrm{~mL})$ was added, and the mixture was refluxed in the dark for 1 hour. After cooling, the purple mixture was concentrated in vacuo in the dark. Purification of the resulting deep-purple solid by 




Figure 1 Synthesis of CTet. Homo-coupling of 2,3'-DIM in the presence of formaldehyde in acidic conditions is shown. Methanol was the solvent, and the mixture was refluxed for 1 hour in the dark. CTet, indole-3-carbinol cyclic tetrameric derivative.

two short and fast aluminum oxide column chromatographies (cyclohexane/EtOAc 8:2) that were protected from light gave a white solid consisting (HPLC/MS) of a 2:1 mixture of $\mathrm{C} \operatorname{Tr}(5,6,11,12,17,18$-esahydrocyclonona [1,2-b:4,5-b':7,8-b'] triindole) and CTet (yield: $45 \%, 0.117$ $\mathrm{g})$, which was recrystallized from acetone $(12 \mathrm{~mL})$. CTet was obtained as a pure white solid. CTet yield was $16 \%$ (0.041 g). Melting point, ${ }^{1} \mathrm{H}-\mathrm{NMR}$, and ${ }^{13} \mathrm{C}$-NMR are in accordance with the literature [21].

\section{Cell culture}

The human breast carcinoma $\mathrm{ER}^{+}$(MCF-7, BT-474) and triple-negative (MDA-MB-231, BT-20) cell lines were cultured in Dulbecco's modified Eagle's medium supplemented with $10 \%$ fetal calf serum, $2 \mathrm{mM} \mathrm{L}$-glutamine, $10 \mathrm{~g} / \mathrm{L}$ non-essential amino acid, $50 \mathrm{mg} / \mathrm{L}$ streptomycin, 1,000 $\mathrm{U} / \mathrm{L}$ penicillin, and $10 \mathrm{mg} / \mathrm{L}$ insulin (in MCF-7 cells) at $37^{\circ} \mathrm{C}$ in a humidified incubator with $5 \% \mathrm{CO}_{2}$. For the in vivo experiments, MCF-7 cells were cultured in complete medium supplemented with $1 \mathrm{nM} \beta$-estradiol 17-cypionate for 2 weeks. All cell culture materials were purchased from Sigma-Aldrich. CTet was formulated with aqueous $\gamma-\mathrm{CD}$ solution as reported by Lucarini and colleagues [21]. In all experiments, $10 \mu \mathrm{L}$ of the concentrated agent was added to $1 \mathrm{~mL}$ of cell culture medium (vehicle control, $10 \mu \mathrm{L}$ of aqueous solution of $\gamma-\mathrm{CD}$ ).

\section{Cell treatments}

Cell proliferation was evaluated by using a $\left[{ }^{3} \mathrm{H}\right]$ thymidine (Sigma-Aldrich) incorporation assay. Cells were seeded at a density of 30,000 per well in 24-well tissue culture plates and allowed to attach overnight. Duplicate samples were treated for 72 hours with increasing concentrations of CTet (from 0.5 to $8.0 \mu \mathrm{M}$ ). During the last 5 hours of treatment, cells were pulsed with $3 \mu \mathrm{Ci}$ / well of $\left[{ }^{3} \mathrm{H}\right]$ thymidine $(25 \mathrm{Ci} / \mathrm{mmol})$ and processed as reported by Brandi and colleagues [20]. Briefly, cells were washed three times with ice-cold trichloroacetic acid $(10 \% \mathrm{wt} / \mathrm{vol})$ and lysed with $300 \mu \mathrm{L}$ of $0.3 \mathrm{~N}$ $\mathrm{NaOH}$. Aliquots $(150 \mu \mathrm{L})$ of lysate were transferred into scintillation vials and processed for liquid scintillation counting. The results are expressed as the percentage of average count-per-minute value in drug-treated samples compared with control samples.

In a set of experiments, one batch of CTet was suspended in pure ethanol and aliquoted to evaluate the activity in different storing conditions. One aliquot was diluted in $\gamma-\mathrm{CD}$ and immediately tested in the antiproliferative assay. Three aliquots were stored at the following conditions: (a) room temperature and exposed to light, (b) room temperature and protected from light, and (c) $+4^{\circ} \mathrm{C}$ and protected from light. Three other aliquots were diluted 1:10 in aqueous solutions of $\gamma-C D$ and stored at the same conditions. The antiproliferative activity was evaluated in MCF-7 cells by using a $\left[{ }^{3} \mathrm{H}\right]$ thymidine incorporation assay at different time points up to 1 year.

For the gene expression, immunoblot, and cell cycle analyses, breast cancer cells were plated in six-well culture plates at a density of 150,000 cells per well and were cultured overnight. Cellular treatments were conducted at increasing concentrations of CTet or vehicle control for 24 and 48 hours. Cell survival was then evaluated by trypan blue dye exclusion assay, and after washing in phosphate-buffered saline (PBS), the cells were pelletted by centrifugation and immediately used for cell cycle analysis or stored at $-20^{\circ} \mathrm{C}$ (for successive immunoblot or gene expression analyses). Cellular pellets prepared for gene expression analysis were stored with $300 \mu \mathrm{L}$ of RNA-later (Sigma-Aldrich). 


\section{High-performance liquid chromatography analyses}

Quantitative determinations of CTet were performed by using an HPLC-UV method (JASCO Model PU-980). The compound was separated at room temperature on a Tracer Excel 120 ODSA $5 \mu \mathrm{m} 15 \times 0.46$ column protected by a guard column (Pelliguard LC-18, $20 \mathrm{~mm} \times$ $4.6 \mathrm{~mm}$ internal diameter, $40 \mu \mathrm{m}$ ); columns were from Teknokroma (Barcelona, Spain). CTet was quantified by UV detection at $280 \mathrm{~nm}$. The volume injected was 50 $\mu \mathrm{L}$. The mobile phase consisted of two eluents: $100 \%$ $\mathrm{H}_{2} \mathrm{O}$ (buffer A) and 100\% acetonitrile (buffer B). CTet was eluted at a flow rate of $1.0 \mathrm{~mL} /$ minute and the following steady gradient program: $100 \%$ buffer A for 3 minutes, taken to $40 \%$ buffer B over the next 12 minutes, and rising to $80 \%$ buffer B from 15 to 25 minutes. This condition was held for 5 minutes, and the gradient was returned to $100 \%$ buffer A in 5 minutes.

\section{Cell cycle analysis}

Cell cycle was analyzed by means of the propidium iodide staining procedure previously reported [23]. Briefly, cells were fixed in ice-cold 70\% ethanol solution $\left(16\right.$ hours at $\left.+4^{\circ} \mathrm{C}\right)$ and stained in propidium iodide solution $(0.1 \%$ sodium citrate, $0.1 \%$ Triton X-100, 250 $\mu \mathrm{g} / \mathrm{mL}$ RNase A, and $50 \mu \mathrm{g} / \mathrm{mL}$ propidium iodide). Cytofluorimetric acquisitions and sample analysis were performed with a Partec PAS flow cytometer (Partec, Münster, Germany) and FlowJo 8.6.3 software (TreeStar, Inc., Ashland, OR, USA), respectively.

\section{Autophagy detection by immunofluorescence analyses} MCF-7 and MDA-MB-231 cells were grown in complete medium on glass coverslips in six-well plates. After 24 hours of attachment, cells were treated with CTet for 4, 8, 12, and 24 hours. At the end of each treatment, cells were fixed with PBS (containing 4\% formaldehyde) for 15 minutes and permeabilized with methanol/acetone solution for 15 minutes at room temperature. To assess the co-localization of LC3b (microtubule-associated protein 1 light chain 3 ) with the lysosome marker LAMP2a (lysosome-associated membrane protein type $2 \mathrm{a}$ ), cells were incubated with a mixture containing the anti-LC3b (Sigma-Aldrich) and LAMP2a (Abcam, Cambridge, UK) primary antibodies, washed, and then probed with goat anti-rabbit AlexaFluor498 and goat anti-mouse AlexaFluor594 secondary antibodies. Nuclei were counterstained with $0.1 \mu \mathrm{g} /$ mL 4'-6-diamidino-2-phenylindole (DAPI). Images were acquired by a Nikon Eclipse E600 microscope (Nikon Corporation, Tokyo, Japan) with ACT-1 software and were processed with an Adobe Photoshop Image Reader 7.0 (Adobe Systems Incorporated, San Jose, CA, USA).

\section{Gene expression analysis}

\section{RNA extraction and microarray analysis}

Whole genome microarray analysis was performed on a CodeLink Expression Bioarray System (GE Healthcare, Piscataway, NJ, USA) on either MCF-7 or MDA-MB231 cells treated with 6 and $12 \mu \mathrm{M}$ CTet for 24 hours. Total RNA was purified from treated and control cells by using an RNeasy plus kit (Qiagen, Hilden, Germany). The RNA was quantified spectrophotometrically by using a Nanodrop ND-1000 (Thermo Fisher Scientific, Waltham, MA, USA); RNA integrity was evaluated on an Experion automated gel electrophoresis system (Bio-Rad Laboratories, Inc., Hercules, CA, USA). Biotinlabeled cRNA was synthesized by using a CodeLink iExpress Assay reagent kit (GE Healthcare) in accordance with the protocols of the manufacturer. Biotin-labeled cRNA obtained from each control or treated biological sample was fragmented and hybridized against three independent arrays $\left(10 \mu \mathrm{g}\right.$ each) at $37^{\circ} \mathrm{C}$ for 22 hours (that is, three replicates for each biological sample). After hybridization, the arrays were washed, stained with Cy5-streptavidin, and scanned with a ScanArray GX scanner (PerkinElmer, Waltham, MA, USA) with a resolution of $5 \mu \mathrm{m}$.

The image files generated by the scanner were processed with CodeLink Expression Analysis software (GE Healthcare). Normalized data from the CodeLink software package were analyzed with GeneSifter software (Geospiza, Inc., Seattle, WA, USA) [24] for statistical validation and data mining. This comprehensive software also generated gene ontology (GO) and z-score reports. The z-score is useful for ranking GO terms by their relative amounts of gene expression changes. Positive $\mathrm{z}$-scores indicate $\mathrm{GO}$ terms with a number of differentially expressed genes higher than expected by chance, whereas negative z-scores indicate GO terms with a number of differentially expressed genes lower than expected by chance [25]. The whole data set obtained from the two experiments on MCF-7 and MDA-MB231 cells, both including technical replicates for each control and treated sample, was subjected to analysis of variance (ANOVA) and 5\% false discovery rate calculation [26]. The cutoff parameters for differential gene expression were $P$ value of 0.01 and fold change threshold of 2. Microarray data are available in the MIAME (minimum information about a microarray experiment)compliant ArrayExpress database [27] (accession number [ArrayExpress:E-MEXP-2989]).

\section{Quantitative real-time polymerase chain reaction}

Real-time polymerase chain reaction (RT-PCR) was used to validate the gene expression profiles observed in the CodeLink microarray experiments. cDNA was synthesized from the same total RNA used for microarray 
experiments, and the SuperScript First Strand Synthesis System for RT-PCR (Invitrogen Corporation, Carlsbad, CA, USA) with oligo-dT priming was used. Primers for amplification of $p 27 / C D K N 1 B$ were p27F 5'-GCAGGAATAAGGAAGCGACCT-3' and p27R 5'-TCCACAGAACCGGCATTTG-3', whereas primers for the amplification of $p 21 / C D K N 1 A$ and GADD45A (growth arrest and DNA-damage-inducible protein alpha), together with primers for the amplification of housekeeping genes $A C T B$ (actin- $\beta$ ) and GAPDH (glyceraldehyde-3-phosphate dehydrogenase), have been described elsewhere [23]. All primer pairs spanned an intron to avoid amplification of contaminating genomic DNA. RT-PCRs were performed in triplicate in a final volume of $25 \mu \mathrm{L}$ by using SYBR green PCR master mix (Applied Biosystems, Foster City, CA, USA) with 200 nM primers in a RotorGene 6000 instrument (Corbett Life Science, Sydney, Australia). The cycling protocol was $95^{\circ} \mathrm{C}$ for 10 minutes followed by 40 cycles at $95^{\circ} \mathrm{C}$ for $10 \mathrm{sec}-$ onds and $60^{\circ} \mathrm{C}$ for 45 seconds. At the end of each run, a melting curve analysis from $55^{\circ} \mathrm{C}$ to $90^{\circ} \mathrm{C}$ was performed to ensure the absence of primer dimers or nonspecific products. Fold changes were calculated by using the comparative quantification application of the RotorGene 6000 software. RT-PCR-based gene expression analysis was also repeated on two new sets of biological samples, from both MCF-7 and MDA-MB231 cells

\section{Immunoblot analysis}

Untreated and CTet-treated cells were lysed for $20 \mathrm{~min}$ utes on ice with $20 \mathrm{mM}$ HEPES (pH 7.9), 25\% glycerol, $0.42 \mathrm{M} \mathrm{NaCl}, 0.2 \mathrm{mM}$ EDTA, $1.5 \mathrm{mM} \mathrm{MgCl}_{2}, 0.5 \%$ Nonidet P-40, and $1 \times$ Complete protease inhibitor cocktail (Roche Diagnostics Ltd., Mannheim, Germany). Cell lysate was frozen and thawed twice and clarified by centrifugation at 12,000 revolutions per minute (rpm) for 10 minutes at $4^{\circ} \mathrm{C}$. The subcellular fraction was obtained as follows: cells were lysed for 10 minutes on ice with $10 \mathrm{mM}$ HEPES (pH 7.9), $1.5 \mathrm{mM} \mathrm{MgCl}_{2}, 10 \mathrm{mM} \mathrm{KCl}$, $1 \mathrm{mM}$ EDTA, $1 \mathrm{mM} \mathrm{Na} \mathrm{VO}_{4}, 1 \mathrm{mM} \mathrm{NaF}, 1 \mathrm{mM}$ DTT, $0.1 \%$ Nonidet P-40, and $1 \times$ Complete protease inhibitor cocktail. Samples were then centrifuged at $12,000 \mathrm{rpm}$ for 10 minutes at $4{ }^{\circ} \mathrm{C}$ to obtain the cytosolic fraction (supernatant); the pellet was resuspended in $20 \mathrm{mM}$ HEPES (pH 7.9), 25\% glycerol, $0.42 \mathrm{M} \mathrm{NaCl}, 0.2 \mathrm{mM}$ EDTA, $1.5 \mathrm{mM} \mathrm{MgCl} 2,1 \mathrm{mM} \mathrm{Na}_{3} \mathrm{VO}_{4}, 1 \mathrm{mM} \mathrm{NaF}$, $1 \mathrm{mM}$ DTT, and $1 \times$ Complete protease inhibitor cocktail, incubated 20 minutes on ice, and centrifuged at $12,000 \mathrm{rpm}$ for 10 minutes at $4^{\circ} \mathrm{C}$ to obtain the nuclear fraction (supernatant).

Proteins extracted were fractionated on 12\% (p27 and p21) and 7.5\% (Akt, phospho-Akt, and FOXO3a) SDSPAGE and then electrically transferred to Trans-Blot transfer medium $(0.2 \mu \mathrm{m})$ nitrocellulose membrane (Bio-Rad Laboratories, Inc.). Blots were incubated with anti-p27 (1:500) and anti-p21 (1:200) antibodies purchased from Santa Cruz Biotechnology, Inc. (Santa Cruz, CA, USA), anti-Akt and anti-phospho-Akt(Ser473) antibodies purchased from Cell Signaling Technology (Danvers, MA, USA), and anti-FKHRL1/FOXO3a $(1: 1,000)$ antibody purchased from Upstate (now part of Millipore Corporation, Billerica, MA, USA) overnight at $4^{\circ} \mathrm{C}$ and then 1 hour at room temperature with peroxidase-conjugated secondary antibody. Blots were treated with enhanced chemiluminescence reagents, and all of the proteins were detected and quantitated by ChemiDoc System (Bio-Rad Laboratories, Inc.). Equal protein loading was confirmed by the level of actin protein present in the membrane tested with anti-actin antibody 1:500 (Sigma-Aldrich).

\section{In vivo tumor growth inhibition}

Housing and treatment of mice were in compliance with the Guide for the Care and Use of Laboratory Animals by Ministero della Sanità D.L. 116 (1992) and approved by the university committee for animal experiments. Female athymic Crl:CD-1-nu/nuBR nude mice (4 weeks of age) (Charles River Laboratories, Milan, Italy) were housed under pathogen-free conditions. The mice were acclimated for 1 week.

Beta-estradiol 17-cypionate (Sigma-Aldrich) was intramuscularly injected at $3 \mathrm{mg} / \mathrm{kg} 1$ week before MCF-7 cells were transplanted into the animal and then once weekly for the duration of the experiment to support the growth of the estrogen-dependent MCF-7 tumors. The cells were inoculated subcutaneously at $1.1 \times 10^{6}$ cells per inoculum on one flank in a final volume of $200 \mu \mathrm{L}$ containing $100 \mu \mathrm{L}$ of Matrigel (BD Biosciences, San Jose, CA, USA) and $100 \mu \mathrm{L}$ of cells suspended in $0.9 \% \mathrm{NaCl}$

Twenty days after the cell inoculation, the mice received the $\mathrm{CTet}$ intraperitoneally at the concentration of $5 \mathrm{mg} / \mathrm{kg}$ per day for 5 days per week for a total of 2 weeks. The mice in the control (placebo) group received the same volume of the vehicle as the CTettreated mice. At least four animals were studied for each experimental group. Each xenograft was monitored by using a calliper to externally measure tumors in two dimensions. Tumor volume (in cubic millimeters) was calculated as $a^{2} \times b \times 0.5$, where $a$ is the length and $b$ is the width of the tumor.

\section{Statistical analyses}

Data are expressed as mean \pm standard error of the mean of at least three separate experiments. The half inhibitory concentration $\left(\mathrm{IC}_{50}\right)$ values of antiproliferative activity were calculated by nonlinear regression by using 
the equation $\mathrm{y}=100-$ Top $\cdot \mathrm{x}^{\text {(HillSlope })} /\left(\mathrm{IC}_{50}{ }^{\text {(HillSlope })}+\right.$ $\mathrm{x}^{\text {(Hillslope) }}$ (Prism5; GraphPad Software, Inc., La Jolla, CA, USA). Statistical analysis was performed by using the Mann-Whitney test or one-way ANOVA followed by Tukey post hoc test as appropriate (Prism5).

\section{Results}

\section{Synthesis of CTet}

The protocol herein reported to obtain CTet was optimized in terms of reagents, temperature, and time. The developed method proved to be reproducible with regard to CTet/CTr ratio and yield (Additional file 1, CTr formation).

\section{Antiproliferative activity of CTet}

It has been previously reported that CTet formulated with $\gamma$-CD is able to inhibit proliferation of both MCF-7 and MDA-MB-231 breast cancer cell lines [21]. In this study, we confirm the dose-dependent activity of CTet in both MCF-7 $\left(\mathrm{IC}_{50}=1.32 \pm 0.03 \mu \mathrm{M}\right)$ and MDA-MB$231\left(\mathrm{IC}_{50}=1.00 \pm 0.01 \mu \mathrm{M}\right)$. In addition, we investigated the drug effect on DNA synthesis in two other breast cancer cell lines: BT474 $\left(\mathrm{ER}^{+}\right)$and BT-20 (triplenegative) (Figure 2). The $\mathrm{IC}_{50}$ values obtained in the two cell lines were $2.64 \pm 0.28$ and $6.69 \pm 0.37 \mu \mathrm{M}$, respectively.



Figure 2 Antiproliferative activity of the CTet formulated in $\gamma$-cyclodextrin aqueous solution. Estrogen receptor-positive (MCF-7 and BT-474) and triple-negative (MDA-MB-231 and BT-20) human breast cancer cell lines were exposed to increased concentrations of $\mathrm{CTet}$. Cell proliferation was evaluated by $\left[{ }^{3} \mathrm{H}\right]$ thymidine incorporation into cellular DNA after 72 hours of treatment. Results are shown as the percentage of $\left[^{3} \mathrm{H}\right]$ thymidine incorporation in treated cells compared with control cells (vehicle only). Data are expressed as mean \pm standard error of the mean of at least three separate experiments. CTet, indole-3-carbinol cyclic tetrameric derivative.

\section{Analysis of cell cycle perturbations}

Cell cycle analysis was carried out in MCF-7 and MDAMB-231 to evaluate the effect of CTet on cell cycle progression. Cells were treated with CTet for 24 and 48 hours at the final concentrations of 4.0 and $8.0 \mu \mathrm{M}$ and then stained with propidium iodide for flow cytometric analyses. Results showed that $C$ Tet induced $\mathrm{G}_{2} / \mathrm{M}$ accumulation in both MCF-7 and MDA-MB-231 cells (Figure 3). After 48 hours of treatment, the cellular population in the $\mathrm{G}_{2} / \mathrm{M}$ phase significantly increased from $19.7 \% \pm 0.9 \%$ to $25.4 \% \pm 0.9 \%$ in MCF-7 and from $19.5 \% \pm 1.5 \%$ to $26.1 \% \pm 0.6 \%$ in MDA-MB-231 $(P<0.05)$.

\section{CTet-treated MDA-MB-231 cells show morphological features of autophagy}

Although the exposure of breast cancer cells to CTet failed to induce apoptosis, specific morphological features of autophagy were detectable in drug-treated MDA-MB-213 cells. In particular, in cells exposed at different time points to $8.0 \mu \mathrm{M}$ CTet, the occurrence of autophagy was assessed by immunofluorescence analysis of LC3b protein. The LC3b protein is recruited to the autophagosome membrane during the autophagy process; consequently, changes in the intracellular localization of LC3b provide a reliable molecular marker for the detection of autophagy. A significant increase in the percentage of MDA-MB-231 cells with a characteristic punctate pattern of LC3b expression was appreciable following exposure to CTet (Figure 4a). Fusion between autophagosomes and lysosomes also represents an important regulatory step of autophagy pathway and can be monitored by co-localization of LC3b and lysosome markers LAMP1 or LAMP2a. In MDA-MB-231 cells, autophagic vescicles were found to co-localize with lysosome after exposure to CTet, as demonstrated by the overlapping of LC3b and LAMP 2 a signals in combined immunofluorescence experiments (Figure 4b; Additional file 2, Figure S1). Taken together, these results indicate that autophagic lysosomal activity is significantly upregulated in MDA-MB-231 as a consequence of CTet exposure. Autophagy features have been transiently observed also in MCF-7 cells following exposure to the highest CTet concentration (data not shown).

\section{Changes of gene expression profile induced by CTet in MCF-7 and MDA-MB-231 cell lines}

The molecular mechanisms involved in CTet response in MCF-7 and MDA-MB-231 cells lines were investigated by means of microarray technology. Both cell lines were treated with 6.0 and $12.0 \mu \mathrm{M}$ CTet for 24 hours before cell harvesting. This early time point was chosen with the aim of observing the changes in gene expression before they have an effect on cell metabolism. 


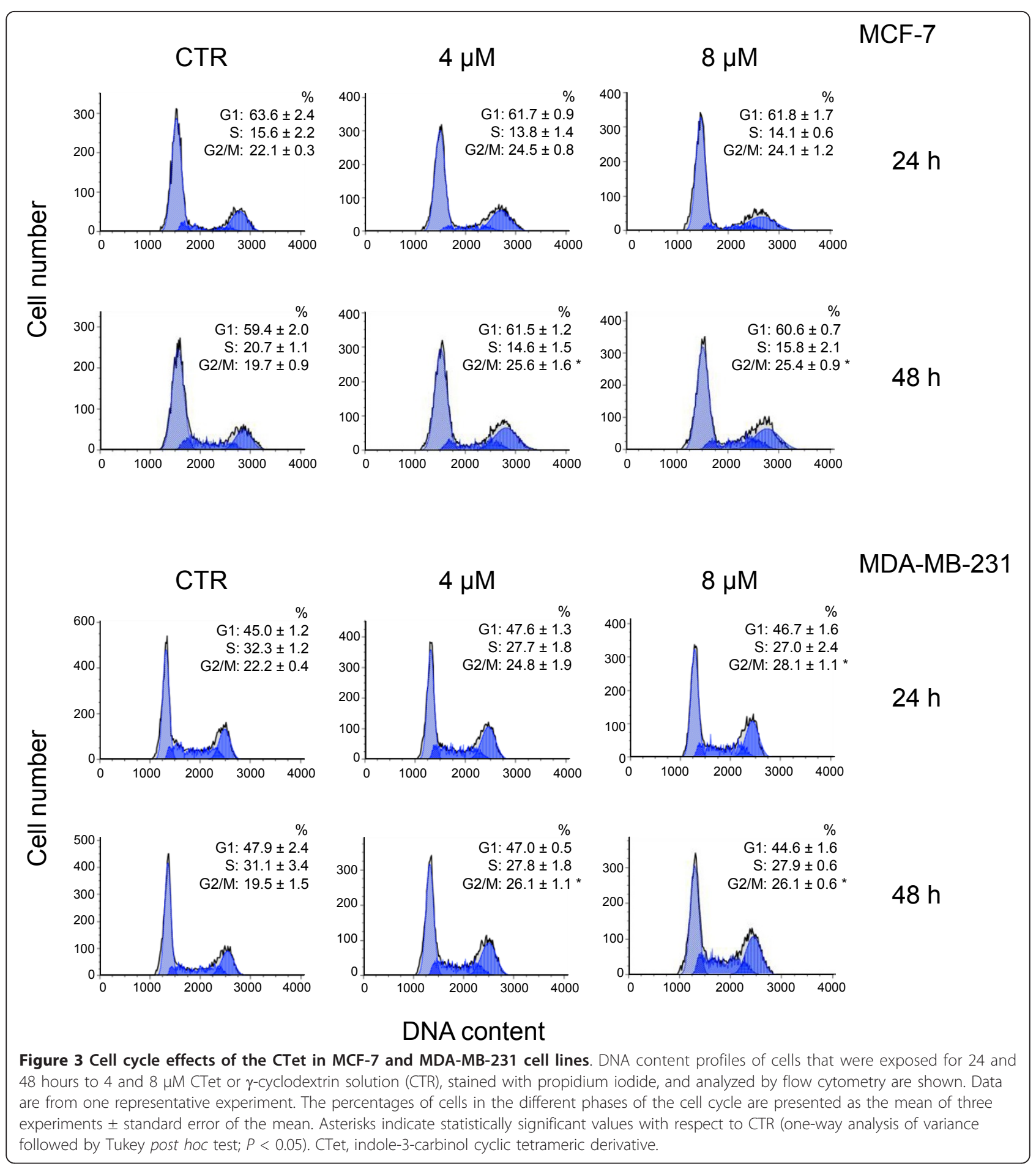

Since the antiproliferative activity and biological responses of CTet were similar among cell lines and independent from the hormonal receptor status, the genes sharing a common expression pattern in both MCF-7 and MDA-MB-231 cell lines, in either 6.0 or $12.0 \mu \mathrm{M}$ CTet treatment conditions, were selected with GeneSifter software.
First, when a differential expression cutoff of 2 (ANOVA, Benjamini-Hochberg false discovery rate correction, $P<0.01$ ) was used, a total of 960 genes differentially expressed in at least one treatment in MCF-7 or MDA-MB-231 cells (or both) were identified. Then, a further analysis of the expression pattern in this subset of genes (Pearson uncentered correlation coefficient of 0.98) 


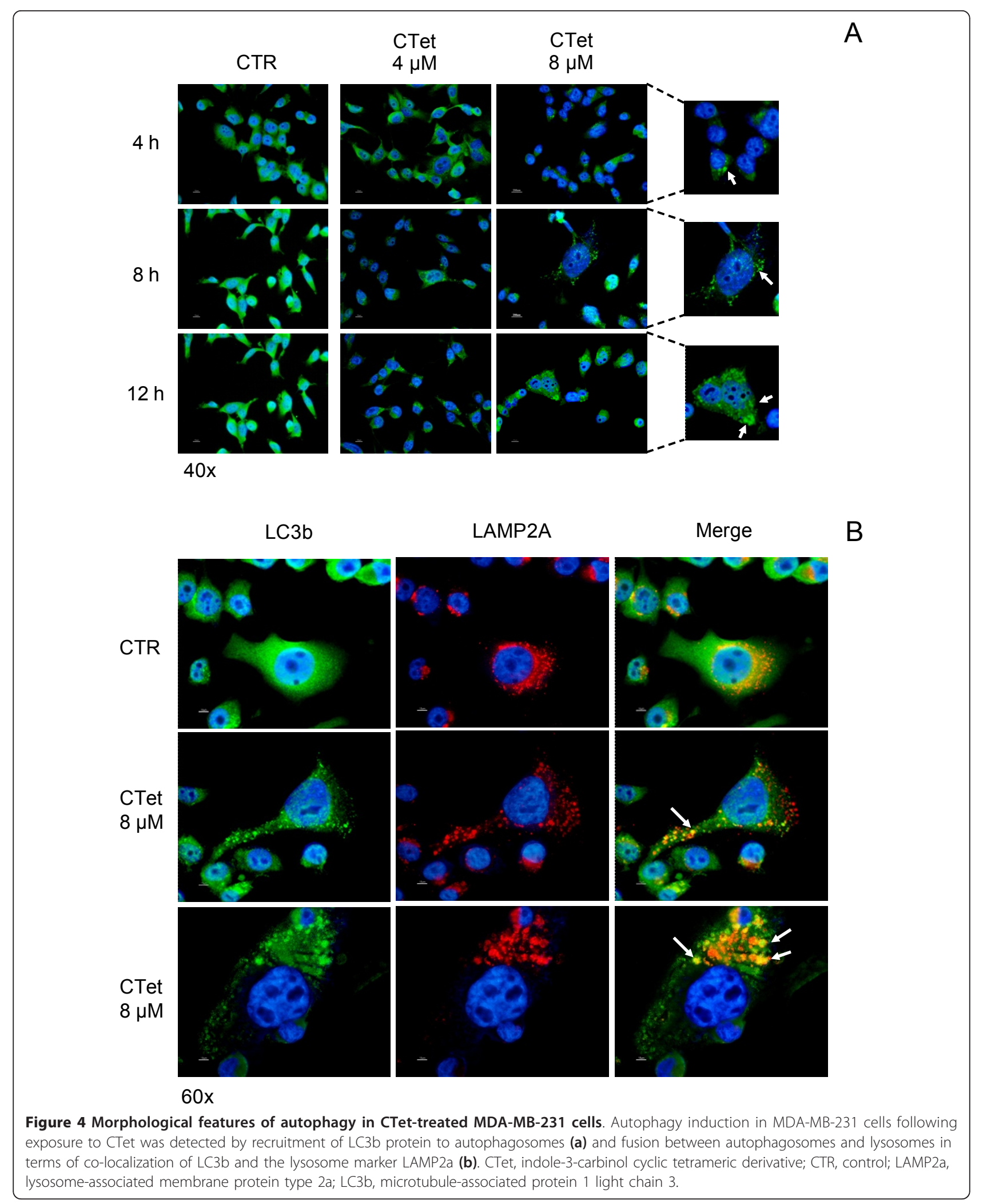


Table 1 Selected ontologies of commonly upregulated genes

\begin{tabular}{|c|c|c|c|}
\hline Term & Genes $^{a}$ & $\begin{array}{c}\text { Gene set on } \\
\text { the array }\end{array}$ & $\begin{array}{c}\text { Z- } \\
\text { score }\end{array}$ \\
\hline \multicolumn{4}{|l|}{ Biological process } \\
\hline Response to stimulus & 39 & 3,137 & 4.82 \\
\hline Response to stress & 27 & 1,753 & 5.05 \\
\hline Response to unfolded protein ${ }^{b}$ & 3 & 62 & 4.14 \\
\hline Acute inflammatory response ${ }^{b}$ & 5 & 99 & 5.5 \\
\hline Acute-phase response $^{b}$ & 4 & 43 & 7.11 \\
\hline $\begin{array}{l}\text { Regulation of acute inflammatory } \\
\text { response }\end{array}$ & 3 & 26 & 6.95 \\
\hline Response to chemical stimulus & 21 & 1,396 & 4.26 \\
\hline Response to organic substance ${ }^{b}$ & 15 & 845 & 4.25 \\
\hline Response to hormone stimulus ${ }^{\mathrm{b}}$ & 10 & 440 & 4.35 \\
\hline $\begin{array}{l}\text { Response to steroid hormone } \\
\text { stimulus }^{b}\end{array}$ & 7 & 220 & 4.75 \\
\hline $\begin{array}{l}\text { Response to glucocorticoid } \\
\text { stimulus }^{\text {b }}\end{array}$ & 6 & 94 & 6.98 \\
\hline Leukocyte chemotaxis $^{\mathrm{b}}$ & 3 & 60 & 4.23 \\
\hline Response to oxygen levels ${ }^{b}$ & 5 & 151 & 4.12 \\
\hline Response to toxin ${ }^{\mathrm{b}}$ & 3 & 64 & 4.05 \\
\hline Response to extracellular stimulus & 7 & 242 & 4.41 \\
\hline $\begin{array}{l}\text { Positive regulation of response to } \\
\text { external stimulus }^{b}\end{array}$ & 4 & 87 & 4.63 \\
\hline $\begin{array}{l}\text { Cellular response to extracellular } \\
\text { stimulus }^{\text {b }}\end{array}$ & 5 & 82 & 6.19 \\
\hline $\begin{array}{l}\text { Cellular response to nutrient } \\
\text { levels }^{b}\end{array}$ & 4 & 62 & 5.73 \\
\hline Cellular response to starvation ${ }^{\mathrm{b}}$ & 3 & 43 & 5.2 \\
\hline Response to biotic stimulus & 10 & 424 & 4.49 \\
\hline Response to virus ${ }^{b}$ & 6 & 147 & 5.24 \\
\hline Cell death & 24 & 1,227 & 6.04 \\
\hline Apoptosis & 22 & 1,116 & 5.8 \\
\hline Regulation of cell death ${ }^{b}$ & 17 & 872 & 4.99 \\
\hline Regulation of apoptosis ${ }^{b}$ & 16 & 859 & 4.62 \\
\hline Negative regulation of cell death ${ }^{b}$ & 10 & 402 & 4.69 \\
\hline Negative regulation of apoptosis ${ }^{\mathrm{b}}$ & 9 & 391 & 4.16 \\
\hline Induction of apoptosis ${ }^{b}$ & 8 & 333 & 4.06 \\
\hline Anti-apoptosis ${ }^{b}$ & 8 & 226 & 5.49 \\
\hline $\begin{array}{l}\text { Positive regulation of anti- } \\
\text { apoptosis }^{\text {b }}\end{array}$ & 3 & 32 & 6.18 \\
\hline $\begin{array}{l}\text { Cellular component disassembly } \\
\text { involved in apoptosis }\end{array}$ & 3 & 27 & 6.81 \\
\hline $\begin{array}{l}\text { Release of cytochrome } c \text { from } \\
\text { mitochondria }^{b}\end{array}$ & 3 & 24 & 7.27 \\
\hline Protein folding & 6 & 158 & 4.99 \\
\hline Leukocyte migration & 4 & 86 & 4.66 \\
\hline Autophagy & 3 & 48 & 4.86 \\
\hline Regulation of synaptic plasticity & 3 & 57 & 4.37 \\
\hline Iron ion homeostasis & 4 & 31 & 8.54 \\
\hline $\begin{array}{l}\text { Positive regulation of smooth } \\
\text { muscle cell proliferation }\end{array}$ & 3 & 28 & 6.67 \\
\hline Regulation of viral reproduction & 3 & 28 & 6.67 \\
\hline \multicolumn{4}{|l|}{ Cellular component } \\
\hline Integral to membrane & 9 & 4,459 & -4.27 \\
\hline Autophagic vacuole & 3 & 20 & 8.2 \\
\hline
\end{tabular}

Table 1 Selected ontologies of commonly upregulated genes (Continued)

\begin{tabular}{llcl}
\hline Molecular functions & & & \\
Heat-shock protein binding & 5 & 71 & 7.14 \\
Unfolded protein binding & 5 & 103 & 5.69 \\
Antioxidant activity & 3 & 45 & 5.35
\end{tabular}

${ }^{a}$ Number of genes differentially expressed within the assigned ontology. ${ }^{\text {b}}$ Subcategory within a given ontology.

revealed that 116 genes were upregulated (search pattern: control $=1 ; 6.0 \mu \mathrm{M}>1 ; 12.0 \mu \mathrm{M}>2$ ) and 177 genes were downregulated (search pattern: control $=1 ; 6.0 \mu \mathrm{M}<1$; $12.0 \mu \mathrm{M}<0.5$ ) in both cell lines (Additional files 3 and 4, Tables S1 and S2, respectively). To explore the biological significance of the transcriptome response shared by the two cell lines, $\mathrm{z}$-score reports containing the most significant $\mathrm{GO}$ terms were generated from the commonly upregulated (Table 1) and downregulated (Table 2) genes. Criteria for selection were GO terms containing at least 20 genes, number of genes differentially expressed within the assigned ontology of at least 3 , and z-score of at least 4 or not more than -4 . The ontology list was then pruned by hand for related GO terms to remove any over-represented branches of the GO hierarchy. When both a parent and a child term were present on the list, the parent term was removed if its presence was due entirely to genes meeting the criterion for the child term.

Concerning the upregulated genes, the main terms in the biological process category included 'response to stimulus' (stress, chemical stimulus, extracellular stimulus, and so on), 'apoptosis', 'protein folding', and 'autophagy'. The cellular components were linked to 'autophagic vacuole' and 'integral to membrane', the latter having a number of differentially expressed genes lower than expected by chance (negative z-score; Materials and methods). In the molecular function category, transcripts were linked to 'heat shock protein binding', 'unfolded protein binding', and 'antioxidant activity' (Table 1).

With respect to downregulated genes, the biological process category included 'cell cycle' and 'DNA metabolic process', whereas the cellular components were linked to 'chromosomal part'. Finally, the molecular functions category included 'transmembrane receptor protein tyrosine kinase activity', 'DNA helicase activity', and 'insulin-like growth factor binding' (Table 2).

To further verify the microarray transcription profile results, selected genes were analyzed by quantitative RTPCR. For these analyses, three genes associated with cell cycle arrest were selected: $p 27 / C D K N 1 B$ (already identified by using CTet previously prepared [20]), GADD45A, and $p 21 / C D K N 1 A$ (identified as $\gamma$-CD-formulated 
Table 2 Selected ontologies of commonly downregulated genes

\begin{tabular}{|c|c|c|c|}
\hline Term & Genes $^{a}$ & $\begin{array}{l}\text { Gene set on } \\
\text { the array }\end{array}$ & $\begin{array}{c}\text { Z- } \\
\text { score }\end{array}$ \\
\hline \multicolumn{4}{|l|}{ Biological process } \\
\hline Cell cycle & 20 & 957 & 4.42 \\
\hline Spindle organization ${ }^{b}$ & 4 & 54 & 5.31 \\
\hline DNA metabolic process & 18 & 559 & 6.32 \\
\hline DNA replication ${ }^{\text {b }}$ & 13 & 228 & 8.13 \\
\hline DNA-dependent DNA replication ${ }^{b}$ & 5 & 71 & 5.75 \\
\hline $\begin{array}{l}\text { DNA-dependent DNA replication } \\
\text { initiation }^{\text {b }}\end{array}$ & 3 & 25 & 6.13 \\
\hline \multicolumn{4}{|l|}{ Cellular component } \\
\hline Chromosomal part & 13 & 381 & 5.57 \\
\hline $\begin{array}{l}\text { Condensed chromosome } \\
\text { kinetochore }\end{array}$ & 4 & 69 & 4.52 \\
\hline Replication fork ${ }^{b}$ & 3 & 33 & 5.2 \\
\hline \multicolumn{4}{|l|}{ Molecular function } \\
\hline $\begin{array}{l}\text { Transmembrane receptor protein } \\
\text { tyrosine kinase activity }\end{array}$ & 4 & 64 & 4.81 \\
\hline DNA helicase activity & 3 & 41 & 4.6 \\
\hline Insulin-like growth factor binding & 3 & 24 & 6.32 \\
\hline
\end{tabular}

${ }^{a}$ Number of genes differentially expressed within the assigned ontology.

${ }^{\mathrm{b}}$ Subcategory within a given ontology.

CTet-induced genes in the microarray experiments). $G A P D H$ was used as a housekeeping gene. Actin- $\beta$ was used in a subset of samples (not shown) as an alternative housekeeping gene to confirm the results obtained with GAPDH. The results (Figure 5) were almost superimposable with those of the microarray experiments, although a greater sensitivity of RT-PCR compared with microarray analysis was revealed. $p 27 / C D K N 1 B$ gene expression appeared unchanged, whereas $p 21 / C D K N 1 A$ showed upregulation in all conditions tested in both cell lines. Moreover, a significant upregulation of GADD45A gene was observed in both MCF-7 and MDA-MB-231 cell lines, although the microarray experiment did not show any significant upregulation in the latter cell line. The quantitative RT-PCR analysis has also been performed on two new sets of biological samples, from either MCF-7 or MDA-MB-231 cells, confirming the upregulation of $p 21 /$ CDKN1A and GADD45A. The average data obtained from three biological samples are shown in Figure S2 of Additional file 5.

\section{Immunoblot analysis}

The significant upregulation of $p 21 / C D K N 1 A$ CDKs inhibitor gene, monitored by microarray studies, was further investigated at the protein level by immunoblot analysis. The results showed that $\mathrm{p} 21 / \mathrm{CDKN} 1 \mathrm{~A}$ was overexpressed in both MCF-7 and MDA-MB-231 cell lines after 24 hours of treatment ( $>7$-fold to actin) and in MCF-7 cells after 48 hours of treatment ( $>9$-fold to actin) (Figure 6). Unlike in previous results [20], CTet formulated did not induce p2 $7^{\mathrm{kip} 1}$ (cyclin-dependent kinase inhibitor 1B) overexpression in MCF- 7 and MDA-MB-231 cells. Further investigations were therefore directed to establish the involvement of FOXO3a transcription factor localization and Akt activity, both of which are involved in p21/CDKN1A expression [28,29]. To evaluate the role of the PI3K/Akt pathway in p21/ CDKN1A expression in CTet-treated breast cancer cell lines, Akt activity was detected by using a specific antiphospo-Akt antibody, the phosphorylated form of Akt protein. The results showed that, in both MCF-7 and MDA-MB-231, phospho-Akt decreases after 48 hours of treatment (about 0.8 -fold and 0.6-fold to total-Akt in MCF-7 and MDA-MB-231, respectively), whereas the decrement of the cytosolic fraction of phospho-Akt was observed after 24 hours of treatment (about 0.6-fold and 0.4-fold to total-Akt in MCF-7 and MDA-MB-231, respectively) (Figure 6). Akt can inactivate FOXO3a via phosphorylation and subsequent translocation to cytosol, but in CTet-treated cells, there was no evidence of variation in FOXO3a localization, suggesting that this transcription factor was not involved in the overexpression of p21/CDKN1A.

\section{Effect of CTet on xenograft tumor growth in athymic nude mice}

Toxicity studies aimed at establishing median lethal dose (LD50) showed that CTet in the concentration range of 0.5 to $15 \mathrm{mg} / \mathrm{kg}$ did not cause any toxic effect (data not shown). To evaluate the potential therapeutic efficacy of systemic administration of CTet, a preliminary experiment was performed in human breast cancer xenograftbearing nude mice. The MCF-7 cells were inoculated subcutaneously on one flank of nude mice as described in Materials and methods. Twenty days after cell inoculation, intraperitoneal treatment with CTet was started at the dose of $5 \mathrm{mg} / \mathrm{kg}$ per day (five treatments a week) and lasted for 2 weeks. The results showed that the treatment blocked the increase of tumor mass, which significantly increased in the animals either not treated or receiving the vehicle (Figure 7). After 2 weeks of treatment, both mice groups receiving CTet or the vehicle did not show any alteration either in body weight or in the hematological parameters with respect to the untreated mice (data not shown).

\section{CTet activity in different storing conditions}

CTet activity in different storing conditions was evaluated up to 1 year. Aliquots of CTet were stored at different conditions of temperature and light exposition (Additional file 6, Table S3), and the activity was evaluated in MCF-7 at different time points $(4,8,12$, and 20 weeks and after 1 year). The results showed that the antiproliferative activity, expressed as $\mathrm{IC}_{50}$, remains 


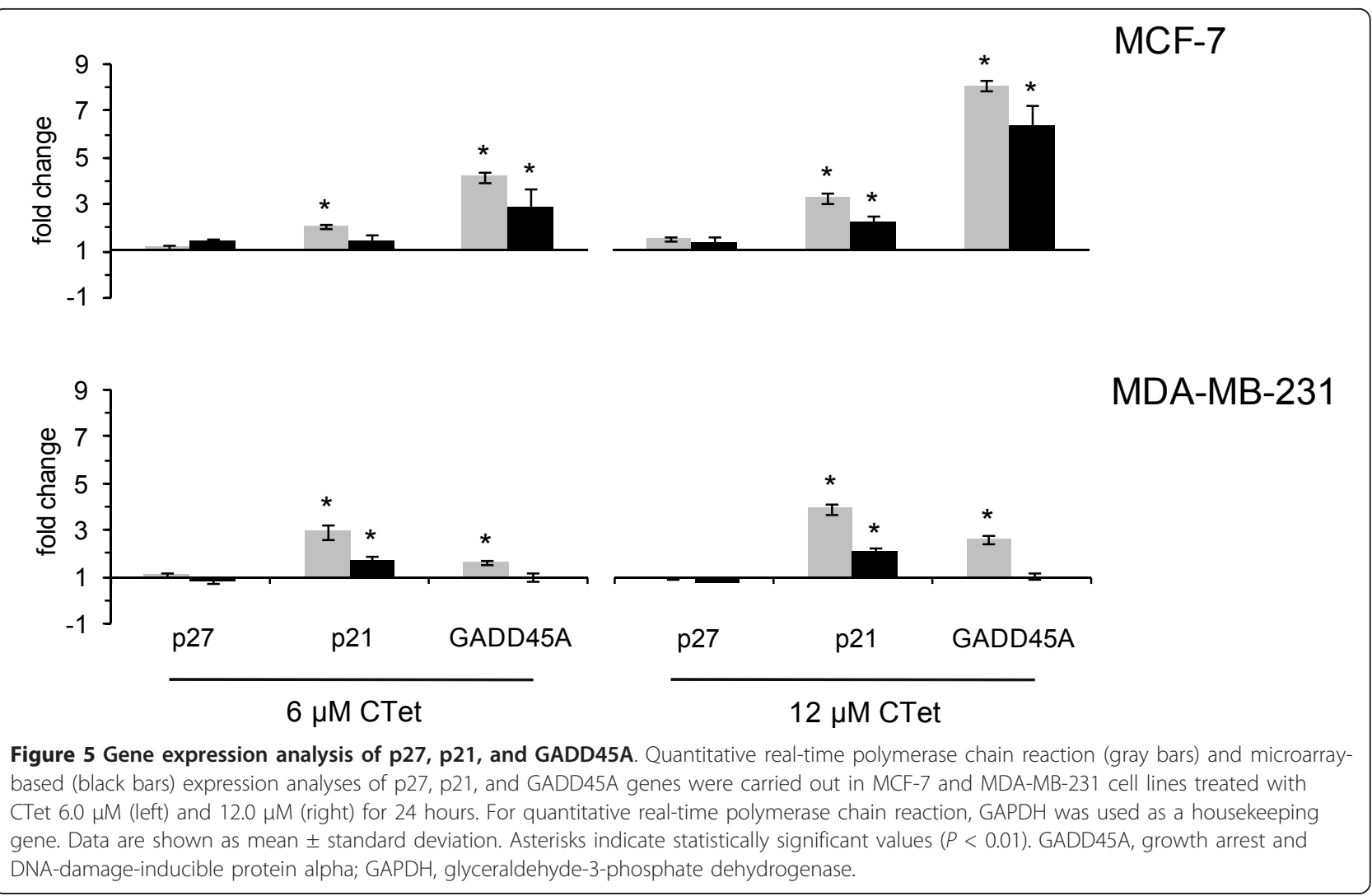

nearly unchanged up to 1 year (Additional file 6, Table S3). Chemical stability of the molecule was assessed by HPLC after 1 year of storage. The chromatographic profile showed that, in all light-protected conditions, more than $95 \%$ of the CTet maintained its chromatographic behavior, confirming the biological data; however, in nonlight-protected conditions, a loss of the molecular integrity ( 15\%) was detected (data not shown).

\section{Discussion}

In the last decades, the mortality rates of breast cancer have decreased [30] as a result of implementation of screening [31], improvements in the local management of early breast cancer [32], and the introduction of adjuvant systemic treatments [33]. However, breast cancer is the leading cause of cancer-related death for women in Europe and the US $[34,35]$. The treatment of a subgroup of breast tumors resistant to targeted therapies - named triple-negative tumors because of a lack of estrogen, progesterone, and HER2/Neu receptors - is a problem that remains unsolved $[1,2]$.

Derivatives of I3C with good antiproliferative activity independently of hormonal receptor status have been widely studied in recent years $[7,8,17-19,36]$. The potential of one of these molecules, the I3C cyclic tetrameric derivative CTet, in the inhibition of breast cancer cell proliferation was shown [20]. However, further analysis revealed that, owing to the presence of other oligomeric derivatives of I3C, the synthetic method previously reported did not give a pure compound.

Recently, Lucarini and colleagues [21] proposed a straightforward synthesis of CTet, but this method, as well as the others reported in the literature $[20,37,38]$, is not sufficiently advantageous. In this paper, we describe a new synthesis involving 2,3'-DIM homo-coupling in the presence of formaldehyde in acidic medium. This synthetic procedure gave an acceptable CTet yield, higher than those already reported $[20,21,37,38]$.

The antiproliferative activity of CTet formulated with $\gamma-C D$, first evaluated in MCF-7 and MDA-MB-231 [21], was confirmed in this study in two additional breast cancer cell lines (BT-474 and BT-20), showing that CTet is able to inhibit cell proliferation about 10fold more than the first formulation in all cell lines tested.

The cell cycle and molecular analyses in MCF-7 and MDA-MB-231 cells treated with formulated CTet did not show the induction of $G_{1}$ cell cycle arrest or the overexpression of CDKs p27 inhibitor as described previously [20]. In fact, CTet inhibited cell proliferation by activating mechanisms resulting in an increased amount of viable cells in the $G_{2} / M$ phase of the cell cycle. 




Autophagy is a multistep process in which cellular proteins and organelles are sequestered, delivered to lysosomes, and digested by lysosomal hydrolases. This process culminates when the nascent autophagosome fuses with the endosomal/lysosomal system to create a fully functional degradative compartment, the autolysosome. By a combined immunofluorescence approach, we were able to detect such a fusion in CTet-treated MDA-
MB-231 cells as the co-localization of the autophagosome marker LC3b and the lysosomal marker LAMP2a [39]. Whether treatment-induced autophagy in these cells represents a survival mechanism or initiates a nonapoptotic cell death remains uncertain [40]. However, the evidence of a significant drug-induced antiproliferative effect in the absence of a clear activation of apoptotic pathways, as observed in gene expression analysis 


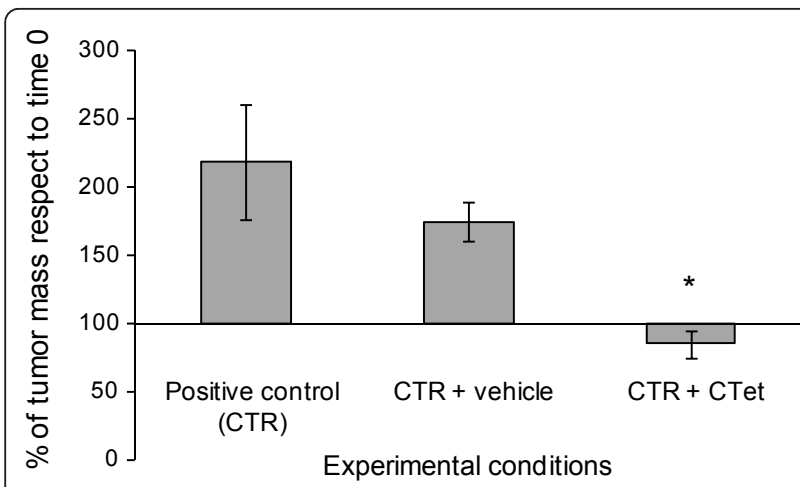

Figure 7 In vivo effects of CTet on the growth of human MCF-7 breast cancer cell-derived tumors from xenografts in athymic mice. Athymic female mice were inoculated with MCF-7 cells and then intraperitoneally treated with CTet $(5 \mathrm{mg} / \mathrm{kg})$ or vehicle ( $\gamma$-cyclodextrin solution) for 2 weeks, as described in Materials and methods. The percentage of residual tumor mass has been calculated with respect to time 0 , which corresponds to the start of treatment. Positive control (CTR) refers to four mice bearing the tumor and not treated, CTR + vehicle refers to four mice bearing the tumor and receiving the vehicle, and CTR + CTet refers to five mice bearing the tumor and receiving CTet. The results are presented as mean \pm standard deviation of the number of mice indicated above. The asterisk indicates statistically significant value with respect to CTR and CTR + vehicle (Mann-Whitney test; $P<0.05)$. CTet, indole-3-carbinol cyclic tetrameric derivative.

(see below), would suggest the possibility that MDAMB-231 cells undergo autophagic cell death.

From gene expression analysis, a reliable list of genes upregulated or downregulated in response to CTet treatment was obtained. Interestingly, several genes involved in suppression of cell proliferation resulted upregulated (for example, IL6, IL8, $221 / C D K N 1 A$, and HBP1) whereas other genes involved in cell cycle progression were downregulated (for example, CDK2, CCNE2, E2F2, $M C M 3$, and $P K M Y T 1$ ), recapitulating the cell cycle profile alterations observed.

The gene expression analysis revealed also the cellular response to the stress/stimulus induced by the drug treatment, through the upregulation of genes involved in oxidative stress response (for example, HMOX1, TXNRD1, and SOD2), xenobiotic metabolism, (for example, $C Y P 1 B 1, A K R 1 C 1$, and $A H R$ ), response to unfolded proteins (for example, DNAJB1, DNAJB4, $D N A J B 9$, and $H S P A 1 A$ ), and inflammatory response (for example, IL6, CEBPB, CCL5, PTGS2, and CFB). Moreover, the upregulation of either pro-apoptotic (for example, $B B C 3, D E D D 2$, and $P M A I P 1)$ or anti-apoptotic (for example, $B A G 3$ and $B E X 2$ ) genes do not provide evidence of any apoptosis induction. In addition, microarray results supported (from a molecular point of view) the autophagy process observed in both cell lines. In fact, the autophagy-related genes WIPI1 (ATG18),
GABARAPL1 (ATG8), MAP1LC3B (LC3B), and SQSTM1 were found upregulated. Moreover, RT-PCR results, besides confirming the upregulation of $p 21 / C D K N 1 A$, showed a significant upregulation of GADD45A gene also in MDA-MB-231 cells.

Altogether, our results suggest that the genes responsible for the arrest of cell proliferation could be the $p 21 /$ $C D K N 1 A$ and GADD45A. The p21 protein is a universal inhibitor of the cyclin-dependent kinase (CDK) family [41] and is able to block cell cycle progression in either the $G_{1} / S$ or the $G_{2} / M$ phase [41-44]. GADD45A interacts with $\mathrm{Cdc} 2$ and inhibits its kinase activity, playing an important role in the regulation of the $\mathrm{G}_{2} / \mathrm{M}$ cell cycle checkpoint $[45,46]$. This finding suggests that CTet treatments inhibit cell cycle progression in breast cancer cells by acting on both $G_{1} / S$ and $G_{2} / M$ cell cycle checkpoints.

The upregulation of $p 21 / C D K N 1 A$ and GADD45A has to be considered not dependent by p 53 induction since p53 gene is mutated in MDA-MB-231 cells $[47,48]$. Moreover, a search for the important transcription factor-binding sites enriched in the selected 116 commonly upregulated genes (Table 4S) by using Distinct Regulatory Elements of co-regulated genes (DiRE) algorithm $[49,50]$ did not show the presence of p53 among the top 50 transcription factors identified (data not shown).

The immunoblot analysis also revealed the inhibition of Akt activity in both cell lines tested. The protein kinase components of protein kinase B (Akt) pathway represent one set of potential targets for treatment of triple-negative tumors [2]. In fact, PI3K and downstream $\mathrm{AKT} /$ protein kinase B family members have been implicated in several cell responses, including the protection of cells from apoptosis, the promotion of cell proliferation, and different metabolic responses [3], and may also be implicated in both p53-dependent and p53-independent expression of $p 21 / C D K N 1 A$ [28] and GADD45A [51]. The inhibition of Akt activity could then play a central role in the antitumoral properties of CTet, as well as I3C and 3,3'-DIM [9-11], and could explain, at least in part, the induction of p53-independent $p 21 /$ $C D K N 1 A$ and GADD45A overexpression in the p53 mutant MDA-MB-231 cell line.

The mechanisms by which CTet-induced overexpression of $p 21 / C D K N 1 A$ and GADD45A, resulting in the inhibition of cell proliferation and autophagy, will be further investigated to establish the eventual involvement of upstream PI3K/AKT or other molecular pathways or both.

The in vivo biological activity of the $\gamma$-CD-formulated CTet was promising since the administration was effective in blocking the increase of tumor mass in xenograft study. Moreover, neither CTet formulation nor $\gamma$-CD aqueous solution alone showed toxicity.

CTet stored in the dark is a very stable molecule. Indeed, more than $98 \%$ of CTet formulated in $\gamma$-CD 
aqueous solution and stored at room temperature and protected from light retained its stability and biological activity up to 1 year $\left(\mathrm{IC}_{50}<1 \mu \mathrm{M}\right)$ in MCF-7 cells. On the whole, the results obtained with $\gamma$-CD formulated CTet are very important because the utilization of dimethyl sulfoxide as a vehicle is not needed $[17,20,36]$.

\section{Conclusions}

Our results showed that CTet is able to induce $G_{2} / M$ cell accumulation and autophagic response in both hormone-responsive and triple-negative breast cancer cells. The overexpression of $p 21 / C D K N 1 A$ could be the main molecular event responsible for the inhibition of cell proliferation, together with the inhibition of Akt activity and the overexpression of GADD45A and the autophagy-related genes. Results from the in vivo study also showed that CTet formulated with $\gamma$-CD is a promising and injectable anticancer agent that deserves additional studies to support the data reported here.

\section{Additional material}

Additional file 1: CTr formation. Plausible mechanisms of $\mathrm{CTr}$

formation in the CTet synthesis.

Additional file 2: Figure S1. Autophagic morphological features induced by serum starvation in MDA-MB-231 cells (positive control) detected by fusion between autophagosomes and lysosomes, in terms of co-localization of LC3b and the lysosome marker LAMP2a.

Additional file 3: Table S1. Transcriptome analysis was performed on MCF-7 and MDA-MB-231 cells treated with $6.0 \mu \mathrm{M}$ and $12.0 \mu \mathrm{M}$ CTet for 24 hours. The genes up-regulated in both MCF-7 and MDA-MB-231 cell lines, either in $6.0 \mu \mathrm{M}$ and $12.0 \mu \mathrm{M}$ CTet treatment conditions, were selected using GeneSifter software. The software analysis allowed to identify a list of 116 genes significantly $(p<0.01)$ up-regulated in both cell lines.

Additional file 4: Table S2. Transcriptome analysis was performed on MCF-7 and MDA-MB-231 cells treated with $6.0 \mu \mathrm{M}$ and $12.0 \mu \mathrm{M}$ CTet for 24 hours. The genes down-regulated in both MCF-7 and MDA-MB-231 cell lines, either in $6.0 \mu \mathrm{M}$ and $12.0 \mu \mathrm{M}$ CTet treatment conditions, were selected using GeneSifter software. The software analysis allowed to identify a list of 177 genes significantly $(p<0.01)$ down-regulated in both cell lines.

Additional file 5: Figure S2. Quantitative real-time PCR of p27, p21 and GADD45A genes were carried out in MCF-7 and MDA-MB-231 cell lines treated with CTet $6.0 \mu \mathrm{M}$ (left) and $12.0 \mu \mathrm{M}$ (right) for 24 hours. Data are shown as mean \pm standard deviation of three separate experiments. Asterisks indicate statistically significant values $(p<0.01)$.

Additional file 6: Table S3. Antiproliferative activity of CTet in different storing conditions in MCF-7 cells. Aliquots of CTet were stored at different conditions of temperature and light exposition and the activity was then evaluated in MCF-7 at different time points $(4,8,12,20$ weeks and after one year). Results are reported as $I_{50}$ values.

\footnotetext{
Abbreviations

Y-CD: gamma-cyclodextrin; ANOVA: analysis of variance; ${ }^{13} \mathrm{C}-\mathrm{NMR}$ : carbon-13 nuclear magnetic resonance; CTet: indole-3-carbinol cyclic tetrameric derivative; CTr: indole-3-carbinol cyclic trimeric derivative; ER: estrogen receptor; GADD45A: growth arrest and DNA-damage-inducible protein alpha; GAPDH: glyceraldehyde-3-phosphate dehydrogenase; GO: gene ontology; ${ }^{1} \mathrm{H}-\mathrm{NMR}$ : proton nuclear magnetic resonance; HPLC: high-performance liquid
}

chromatography; HPLC/MS: high-performance liquid chromatography/mass spectrometry; I3C: indole-3-carbinol; $\mathrm{I}_{50}$ : half inhibitory concentration; LAMP2a: Iysosome-associated membrane protein type 2a; LC3b: microtubule-associated protein 1 light chain 3; mTOR: mammalian target of rapamycin; 2 21/CDKN1A: cyclin-dependent kinase inhibitor $1 \mathrm{~A} ; \mathrm{p} 27^{\mathrm{Kip} 1}$ : cyclindependent kinase inhibitor 1B; PBS: phosphate-buffered saline; PI3K: phosphatidylinositol 3-kinase; PR: progesterone receptor; rpm: revolutions per minute; RT-PCR: real-time polymerase chain reaction.

\section{Acknowledgements}

This work was supported in part by the Italian Association for Cancer Research (AIRC).

\section{Author details}

${ }^{1}$ Department of Biomolecular Sciences, University of Urbino 'Carlo Bo', Via Saffi 2, 61029 Urbino, Italy. ${ }^{2}$ Department of Health and Drug Sciences, University of Urbino 'Carlo Bo', Via Saffi 2, 61029 Urbino, Italy. ${ }^{3}$ Department of Experimental Oncology and Molecular Medicine, Fondazione IRCCS Istituto Nazionale dei Tumori, Via G. Venezian 1, 20133 Milano, Italy.

\section{Authors' contributions}

MM and GB coordinated the studies and helped to design the experiments. MDS performed cell culture experiments and immunoblot analyses and drafted the manuscript. LG carried out the gene expression analyses. SL and AD performed and optimized the synthesis of CTet. MFP and AF carried out the xenograft experiments and HPLC analyses. MF performed the cytofluorimetric analyses. CDM and NZ carried out immunofluorescence analyses for the autophagy detection. All authors helped to draft the manuscript and read and approved the final manuscript.

\section{Competing interests}

MM and GB are listed as inventors on US Patent 7,645,788 ('Tetramerous derivative of indole-3-carbinol with anti-carcinogenic activity and method of synthesis of said derivative'), held by the University of Urbino. The remaining authors declare that they have no competing interests.

Received: 16 November 2010 Revised: 4 February 2011 Accepted: 24 March 2011 Published: 24 March 2011

\section{References}

1. Chacón RD, Costanzo MV: Triple-negative breast cancer. Breast Cancer Res 2010, 12 Suppl 2:S3.

2. Cleator S, Heller W, Coombes RC: Triple-negative breast cancer: therapeutic options. Lancet Oncol 2007, 8:235-244.

3. Coffer PJ, Jin J, Woodgett JR: Protein kinase B (c-Akt): a multifunctional mediator of phosphatidylinositol 3-kinase activation. Biochem J 1998, 335:1-13.

4. Higdon JV, Delage B, Williams DE, Dashwood RH: Cruciferous vegetables and human cancer risk: epidemiologic evidence and mechanistic basis. Pharmacol Res 2007, 55:224-236.

5. Minich DM, Bland JS: A review of the clinical efficacy and safety of cruciferous vegetable phytochemicals. Nutr Rev 2007, 65:259-267.

6. Verhoeven DT, Goldbohm RA, van Poppel G, Verhagen $H$, van den Brandt PA: Epidemiological studies on brassica vegetables and cancer risk. Cancer Epidemiol Biomarkers Prev 1996, 5:733-748.

7. Weng JR, Tsai CH, Kulp SK, Chen CS: Indole-3-carbinol as a chemopreventive and anti-cancer agent. Cancer Lett 2008, 262:153-163.

8. Aggarwal $\mathrm{BB}$, Ichikawa $\mathrm{H}$ : Molecular targets and anticancer potential of indole-3-carbinol and its derivatives. Cell Cycle 2005, 4:1201-1215.

9. Howells LM, Gallacher-Horley B, Houghton CE, Manson MM, Hudson EA Indole-3-carbinol inhibits protein kinase B/Akt and induces apoptosis in the human breast tumor cell line MDA MB468 but not in the nontumorigenic HBL100 line. Mol Cancer Ther 2002, 1:1161-1172.

10. Rahman KM, Li Y, Sarkar FH: Inactivation of akt and NF-kappaB play important roles during indole-3-carbinol-induced apoptosis in breast cancer cells. Nutr Cancer 2004, 48:84-94.

11. Rahman KW, Sarkar FH: Inhibition of nuclear translocation of nuclear factor-\{kappa\}B contributes to 3,3'-diindolylmethane-induced apoptosis in breast cancer cells. Cancer Res 2005, 65:364-371.

12. Grose KR, Bjeldanes LF: Oligomerization of indole-3-carbinol in aqueous acid. Chem Res Toxicol 1992, 5:188-193. 
13. Safe S, Papineni S, Chintharlapalli S: Cancer chemotherapy with indole-3carbinol, bis(3'-indolyl)methane and synthetic analogs. Cancer Lett 2008, 269:326-338.

14. Firestone GL, Bjeldanes LF: Indole-3-carbinol and 3-3'-diindolylmethane antiproliferative signaling pathways control cell-cycle gene transcription in human breast cancer cells by regulating promoter-Sp1 transcription factor interactions. J Nutr 2003, 133:2448S-2455S.

15. Cover CM, Hsieh SJ, Tran SH, Hallden G, Kim GS, Bjeldanes LF, Firestone GL: Indole-3-carbinol inhibits the expression of cyclin-dependent kinase-6 and induces a $G_{1}$ cell cycle arrest of human breast cancer cells independent of estrogen receptor signaling. J Biol Chem 1998, 273:3838-3847.

16. Cram EJ, Liu BD, Bjeldanes LF, Firestone GL: Indole-3-carbinol inhibits CDK6 expression in human MCF-7 breast cancer cells by disrupting Sp1 transcription factor interactions with a composite element in the CDK6 gene promoter. J Biol Chem 2001, 276:22332-22340.

17. Jump SM, Kung J, Staub R, Kinseth MA, Cram EJ, Yudina LN, Preobrazhenskaya MN, Bjeldanes LF, Firestone GL: N-Alkoxy derivatization of indole-3-carbinol increases the efficacy of the $G_{1}$ cell cycle arrest and of I3C-specific regulation of cell cycle gene transcription and activity in human breast cancer cells. Biochem Pharmacol 2008, 75:713-724.

18. Nguyen HH, Lavrenov SN, Sundar SN, Nguyen DH, Tseng M, Marconett CN, Kung J, Staub RE, Preobrazhenskaya MN, Bjeldanes LF, Firestone GL: 1Benzyl-indole-3-carbinol is a novel indole-3-carbinol derivative with significantly enhanced potency of anti-proliferative and anti-estrogenic properties in human breast cancer cells. Chem Biol Interact 2010, 186:255-266.

19. Kronbak R, Duus F, Vang O: Effect of 4-methoxyindole-3-carbinol on the proliferation of colon cancer cells in vitro, when treated alone or in combination with indole-3-carbinol. J Agric Food Chem 2010, 58:8453-8459.

20. Brandi G, Paiardini M, Cervasi B, Fiorucci C, Filippone P, De Marco C, Zaffaroni N, Magnani M: A new indole-3-carbinol tetrameric derivative inhibits cyclin-dependent kinase 6 expression, and induces $\mathrm{G} 1$ cell cycle arrest in both estrogen-dependent and estrogen-independent breast cancer cell lines. Cancer Res 2003, 63:4028-4036.

21. Lucarini S, De Santi M, Antonietti F, Brandi G, Diamantini G, Fraternale A Paoletti MF, Tontini A, Magnani M, Duranti A: Synthesis and biological evaluation of a $\gamma$-cyclodextrin-based formulation of the anticancer agent $5,6,11,12,17,18,23,24-o c t a h y d r o c y c l o d o d e c a\left[1,2-b: 4,5-b^{\prime}: 7,8-b^{\prime \prime}: 10,11-b^{\prime \prime \prime}\right]$ tetraindole (CTet). Molecules 2010, 15:4085-4093.

22. Jackson A, Prasitpan N, Shannon P, Tinker A: Electrophilic substitution in indoles. Part 15. The reaction between methylenedi-indoles and $p$ nitrobenzenediazonium fluoroborate. J Chem Soc Perkin Trans 1 1987, 1:2543-2551.

23. Amatori S, Bagaloni I, Macedi E, Formica M, Giorgi L, Fusi V, Fanelli M: Malten, a new synthetic molecule showing in vitro antiproliferative activity against tumour cells and induction of complex DNA structural alterations. Br J Cancer 2010, 103:239-248.

24. GeneSifter product overview. [http://www.geospiza.com/Products/ AnalysisEdition.shtml].

25. Cheadle C, Vawter MP, Freed WJ, Becker KG: Analysis of microarray data using Z score transformation. J Mol Diagn 2003, 5:73-81.

26. Benjamini $Y$, Hochberg $Y$ : Controlling the false discovery rate: a practical and powerful approach to multiple testing. J R Statist Soc B 1995, 57:289-300.

27. ArrayExpress homepage. [http://www.ebi.ac.uk/arrayexpress/]

28. Manning BD, Cantley LC: AKT/PKB signaling: navigating downstream. Cell 2007, 129:1261-1274

29. Seoane J, Le HV, Shen L, Anderson SA, Massagué J: Integration of Smad and forkhead pathways in the control of neuroepithelial and glioblastoma cell proliferation. Cell 2004, 117:211-223.

30. Levi F, Bosetti C, Lucchini F, Negri E, La Vecchia C: Monitoring the decrease in breast cancer mortality in Europe. Eur J Cancer Prev 2005, 14:497-502.

31. Berry DA, Cronin KA, Plevritis SK, Fryback DG, Clarke L, Zelen M, Mandelblatt JS, Yakovlev AY, Habbema JD, Feuer EJ: Effect of screening and adjuvant therapy on mortality from breast cancer. $N$ Engl J Med 2005, 353:1784-1792

32. Overgaard $M$, Jensen MB, Overgaard J, Hansen PS, Rose C, Andersson M, Kamby C, Kjaer M, Gadeberg CC, Rasmussen BB, Blichert-Toft M,
Mouridsen HT: Postoperative radiotherapy in high-risk postmenopausal breast-cancer patients given adjuvant tamoxifen: Danish Breast Cancer Cooperative Group DBCG 82c randomised trial. Lancet 1999, 353:1641-1648.

33. Early Breast Cancer Trialists' Collaborative Group (EBCTCG): Effects of chemotherapy and hormonal therapy for early breast cancer on recurrence and 15-year survival: an overview of the randomised trials. Lancet 2005, 365:1687-1717.

34. Ferlay J, Autier P, Boniol M, Heanue M, Colombet M, Boyle P: Estimates of the cancer incidence and mortality in Europe in 2006. Ann Oncol 2007, 18:581-592.

35. Jemal A, Siegel $R, X u$ J, Ward E: Cancer statistics, 2010. CA Cancer J Clin 2010, 60:277-300.

36. Rahimi M, Huang KL, Tang CK: 3,3'-Diindolylmethane (DIM) inhibits the growth and invasion of drug-resistant human cancer cells expressing EGFR mutants. Cancer Lett 2010, 295:59-68.

37. Bergman J, Högberg S, Lindström JO: Macrocyclic condensation products of indole and simple aldehydes. Tetrahedron 1970, 26:3347-3352.

38. Staub RE, Bjeldanes LF: Convenient synthesis of $5,6,11,12,17,18$ -

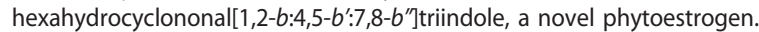
J Org Chem 2003, 68:167-169.

39. Glick D, Barth S, Macleod KF: Autophagy: cellular and molecular mechanisms. J Pathol 2010, 221:3-12.

40. White E, DiPaola RS: The double-edged sword of autophagy modulation in cancer. Clin Cancer Res 2009, 15:5308-5316.

41. Xiong Y, Hannon GJ, Zhang H, Casso D, Kobayashi R, Beach D: p21 is a universal inhibitor of cyclin kinases. Nature 1993, 366:701-704.

42. Wendt J, Radetzki S, von Haefen C, Hemmati PG, Guner D, SchulzeOsthoff K, Dorken B, Daniel PT: Induction of p21 $1^{\text {CIP/WAF-1 }}$ and G2 arrest by ionizing irradiation impedes caspase-3-mediated apoptosis in human carcinoma cells. Oncogene 2006, 25:972-980.

43. Harper JW, Adami GR, Wei N, Keyomarsi K, Elledge SJ: The p21 Cdkinteracting protein Cip1 is a potent inhibitor of $\mathrm{G} 1$ cyclin-dependent kinases. Cell 1993, 75:805-816.

44. Harper JW, Elledge SJ, Keyomarsi K, Dynlacht B, Tsai LH, Zhang P, Dobrowolski S, Bai C, Connell-Crowley L, Swindell E, Fox MP, Wei N: Inhibition of cyclin-dependent kinases by p21. Mol Biol Cell 1995, 6:387-400.

45. Jin $S$, Antinore MJ, Lung FD, Dong $X$, Zhao $H$, Fan F, Colchagie AB, Blanck P, Roller PP, Fornace AJ Jr, Zhan Q: The GADD45 inhibition of Cdc2 kinase correlates with GADD45-mediated growth suppression. J Biol Chem 2000, 275:16602-16608.

46. Gao H, Jin S, Song Y, Fu M, Wang M, Liu Z, Wu M, Zhan Q: B23 regulates GADD45a nuclear translocation and contributes to GADD45a-induced cell cycle $\mathrm{G}_{2}-\mathrm{M}$ arrest. J Biol Chem 2005, 280:10988-10996.

47. Chai Y, Lee HJ, Shaik AA, Nkhata K, Xing C, Zhang J, Jeong SJ, Kim SH, Lu J: Penta-O-galloyl- $\beta$-D-glucose induces $\mathrm{G} 1$ arrest and DNA replicative $\mathrm{S}$ phase arrest independently of P21 cyclin-dependent kinase inhibitor 1A, P27 cyclin-dependent kinase inhibitor 1B and P53 in human breast cancer cells and is orally active against triple-negative xenograft growth. Breast Cancer Res 2010, 12:R67.

48. Li Y, Upadhyay S, Bhuiyan M, Sarkar FH: Induction of apoptosis in breast cancer cells MDA-MB-231 by genistein. Oncogene 1999, 18:3166-3172.

49. Gotea $\mathrm{V}$, Ovcharenko I: DiRE: identifying distant regulatory elements of co-expressed genes. Nucleic Acids Res 2008, 36:W133-139.

50. DiRE (Dlstant Regulatory Elements of co-regulated genes). [http://dire. dcode.org].

51. Zhu QS, Ren W, Korchin B, Lahat G, Dicker A, Lu Y, Mills G, Pollock RE, Lev D: Soft tissue sarcoma cells are highly sensitive to AKT blockade: a role for p53-independent up-regulation of GADD45a. Cancer Res 2008, 68:2895-2903.

doi:10.1186/bcr2855

Cite this article as: De Santi et al:: The indole-3-carbinol cyclic tetrameric derivative CTet inhibits cell proliferation via overexpression of $\mathrm{p} 21 / \mathrm{CDKN} 1 \mathrm{~A}$ in both estrogen receptor-positive and triple-negative breast cancer cell lines. Breast Cancer Research 2011 13:R33. 